\title{
Pilot Performance of Chemical Demulsifier on the Demulsification of Produced Water from Polymer/Surfactant Flooding in the Xinjiang Oilfield
}

\author{
Dong Chen ${ }^{1,2,3}$, Feng Li ${ }^{1,2}$, Yingxin Gao ${ }^{1,2, *}$ and Min Yang ${ }^{1,2}$ \\ 1 State Key Laboratory of Environmental Aquatic Chemistry, Research Center for Eco-Environmental Sciences, \\ Chinese Academy of Sciences, Beijing 100085, China; chendong@rcees.ac.cn (D.C.); fli@rcees.ac.cn (F.L.); \\ yangmin@rcees.ac.cn (M.Y.) \\ 2 University of the Chinese Academy of Sciences, Beijing 100019, China \\ 3 Sino-Danish Center for Education and Research, Beijing 100190, China \\ * Correspondence: gyx@rcees.ac.cn; Tel.: +86-010-628-49149
}

Received: 30 November 2018; Accepted: 13 December 2018; Published: 18 December 2018

\begin{abstract}
Purification of produced water (PW) from polymer/surfactant flooding is a challenge for the petroleum industry due to the high emulsion stability. Demulsification using chemical demulsifiers has been expected to be an effective way to treat PW. In this paper, five cationic (branched quaternary ammonium chloride) and four nonionic (copolymer of propylene oxide and ethylene oxide) demulsifiers with different molecular weights were employed to test their respective demulsification performance in the treatment of PW from polymer/surfactant flooding. The cationic demulsifiers, in general, exhibited better performance than the nonionic ones and one cationic demulsifier (CP-1) exhibiting the best demulsification efficiency was further employed for a pilot experiment in the Xinjiang Oilfield. The oil content of PW could be successfully reduced from 128 7364 to less than $10 \mathrm{mg} / \mathrm{L}$ with a dosage of CP-1 for $350 \mathrm{mg} / \mathrm{L}$ and polyaluminum chloride (PAC, $\left.30 \% w / w \mathrm{Al}_{2} \mathrm{O}_{3}\right)$ for $500 \mathrm{mg} / \mathrm{L}$ under ambient temperature $\left(14 \sim 22{ }^{\circ} \mathrm{C}\right)$. At the same time, partially hydrolyzed polyacrylamide (HPAM) was removed from $176.9 \sim 177.1$ to $2.8 \sim 3.9 \mathrm{mg} / \mathrm{L}$ while petroleum sulfonate was not removed too much (from $35.5 \sim 43.8$ to $25.5 \sim 26.5 \mathrm{mg} / \mathrm{L}$ ). The interfacial rheology analysis on simulated PW from HPAM/petroleum sulfonate flooding revealed that the addition of CP-1 led to a significant increase of the oil-water interfacial tension (from 7 to $15 \sim 20 \mathrm{mN} / \mathrm{m}$ ) and zeta potential (from -32.5 to $-19.7 \mathrm{mV}$ ). It was, thus, assumed that the decreased net charge on the dispersed oil droplets surface and weakened oil/water film due to the formation of complex between the cationic demulsifier and HPAM may have facilitated the destabilization of the emulsion. The result of this study is useful in better understanding the demulsification processes as well as selecting suitable demulsifiers in the treatment of PW from polymer/surfactant flooding.
\end{abstract}

Keywords: produced water; polymer/surfactant flooding; demulsification; demulsifier; interfacial rheology

\section{Introduction}

The enhanced oil recovery (EOR) methods, which use polymers and surfactants to increase oil recovery, are becoming more and more important in maintaining the world oil production [1,2]. After EOR, the residual polymers and surfactants will be left in the produced water (PW), which will result in stable oil/water emulsions. This is difficult to be broken [3-6]. Different approaches including chemical, biological, electrical, or physical technologies have been employed for breaking down the emulsion of PW formed during EOR [7-10]. Among them, demulsification using chemical demulsifiers has been considered the most promising one [11]. 
Since PW formed during EOR contains crude oil, polymers, surfactants, salts, bacteria, and fine solid particles, demulsification of EOR PW has been a big challenge [3]. The selection of a suitable demulsifier is still mainly based on the trial and error after some preliminary screening such as bottle tests [12]. Research on the treatment of the real PW from polymer/surfactant flooding is still quite a few. There are simulation studies on the oil-water separation of the produced liquid from polymer/surfactant flooding, which have shown that cationic demulsifiers (alkyltrimethylammonium bromide) have the ability to form ion pairs with the emulsifiers and reduce charge density of dispersed oil droplets and exhibited outstanding performance [11,13]. In addition, some nonionic demulsifiers such as copolymers of ethylene oxide (EO) and propylene oxide (PO) have the ability to adsorb onto the dispersed oil droplets and replace the emulsifiers with excellent performance in the demulsification of PW from polymer flooding and Marpol oil waste [12,14]. PW from polymer/surfactant flooding is the byproduct of the oil-water separation processes, which contain less oil cut $(<1 \%)$ and come with higher stability than produced liquid. Besides the residual polymer, there are also residual flooding surfactants. Water quality may be different with Marpol oil waste or PW from polymer flooding. The results, therefore, from most of the previous studies may not be applicable to the treatment practice of the real PW from polymer/surfactant flooding.

In this study, five cationic (branched quaternary ammonium chloride) and four nonionic (copolymer of ethylene oxide and propylene oxide) demulsifiers with different molecular weights were tested for their performance in the treatment of the real PW from polymer/surfactant flooding in the Xinjiang Oilfield in China. One cationic demulsifier exhibiting the most efficient demulsification performance was further applied in the field pilot experiment. To explore the demulsification mechanisms, this demulsifier was compared with one showing poor demulsification performance using the interfacial rheology method. The results of this study may provide scientific insights in the demulsification practices of EOR PW.

\section{Experimental Section}

\subsection{Characteristics of Produced Water}

The PW samples were taken from the polymer/surfactant flooding area of the Xinjiang Oilfield over a period from 16 October to 11 November 2014. The samples for water quality analysis were taken three times every day (10:00, 14:00, 16:00). The concentrations of oil and suspended solids were measured after standing for $16 \sim 22 \mathrm{~h}$ and the average values were recorded for each day. The remaining parameters were only measured once since they were very stable.

\subsection{Materials}

Partially hydrolyzed polyacrylamide (HPAM) (Beijing Hengju, Beijing, China) with a molecular weight of $15 \times 10^{6} \mathrm{~g} / \mathrm{mol}$ and hydrolysis degree of $24.1 \%$ (titration method) and petroleum sulfonate (PS) of industrial degree (Daqing Oilfield Company, Daqing, China) were applied for polymer/surfactant flooding in Xinjiang Oilfield and used in this study. Poly aluminum chloride (PAC) of industrial degree (purity: $30 \% w / w \mathrm{Al}_{2} \mathrm{O}_{3}$ ) (Gongyi Satisfying Clean Water Material Co., Ltd., Gongyi, China) was used as a coagulant. N-decane, petroleum ether, and other chemical reagents of analytic degree were purchased from Sinopharm Chemical Reagent Beijing Co., Ltd., Beijing, China. $\mathrm{N}$-decane was used as the oil phase for the interfacial rheology measurement to avoid interference of asphaltene and other active components in crude oil. Five cationic (labeled as CP-1, CP-2, CP-3, CP-4, and CP-5) and four nonionic (labeled as NP-1, NP-2, NP-3, and NP-4) demulsifiers of industrial degree were purchased from Befar Group Co., Ltd., Binzhou, China, and used as received. The detailed molecular weight for each demulsifier was not available, but the larger number corresponds to larger molecular weight. As illustrated in Figure 1, the cationic demulsifiers are branched quaternary ammonium chloride and the nonionic ones are copolymers of $\mathrm{EO}$ and $\mathrm{PO}$ units. 


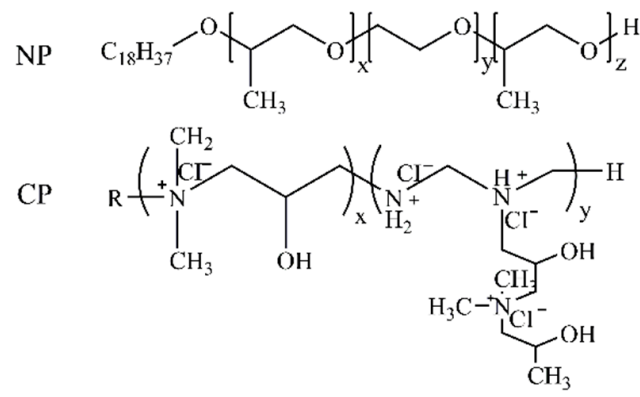

Figure 1. Basic structures of the cationic demulsifiers (CP) and nonionic ones (NP) ( $x, y$ and $z$ are independent for different demulsifier, $\mathrm{R}$ represents the alkyl group).

\subsection{Solution Preparation}

Five hundred mg/L stock solution of HPAM was prepared by adding HPAM slowly to the vortex of distilled water established by magnetic stirring at 500 revolutions per minute (RPM) for $5 \mathrm{~min}$ and then stirred for 5 days at $100 \mathrm{RPM}$. Stock solutions of petroleum sulfonate $(500 \mathrm{mg} / \mathrm{L})$ and demulsifiers $(10,000 \mathrm{mg} / \mathrm{L})$ were also prepared using distilled water. The simulated solutions of HPAM, demulsifiers, or surfactant were prepared by mixing the stock solutions with distilled water and continuously stirred for $4 \mathrm{~h}$ before use.

\subsection{Demulsification Tests}

PW from the polymer/surfactant flooding project in Xinjiang Oilfield containing $358.5 \mathrm{mg} / \mathrm{L}$ crude oil was used to screen demulsifiers. Five $\mathrm{ml}$ demulsifier stock solution (dose, $500 \mathrm{mg} / \mathrm{L}$ ) was added in a test tube containing $100 \mathrm{~mL} \mathrm{PW}$ and shaken by hand for $2 \mathrm{~min}$. The oil content of the supernatant was determined after the test tubes stood for $2 \mathrm{~h}$ at $40{ }^{\circ} \mathrm{C}$. The test was conducted in triplicate for each demulsifier and the average values were used. Then, the demulsification experiment at different demulsifier dosages was conducted under similar conditions using the emulsifier exhibiting the best performance (CP-1). Oil, $\mathrm{pH}$, zeta potential, HPAM, and petroleum sulfonate content in the PW were measured. The measurement of HPAM and petroleum sulfonate was conducted after filtration using a $0.45 \mu \mathrm{m}$ membrane filter. Each experiment was conducted with three replicates and the average value was used.

\subsection{Field Pilot Study}

The pilot plant consists of demulsification, coagulation, sedimentation, and filtration compartments, which is shown in Figure 2. The effective volume for demulsification, coagulation, sedimentation, and filtration were $5.2,1.6,5.2$, and $2.1 \mathrm{~m}^{3}$, respectively. PW was pumped into the system with a flow rate of $50 \mathrm{~m}^{3} / \mathrm{d}$ and $350 \mathrm{mg} / \mathrm{L}$ cationic demulsifier CP-1 and $500 \mathrm{mg} / \mathrm{L}$ PAC were added into the demulsification and coagulation compartments, respectively, under ambient temperature $\left(14.0 \sim 22.0^{\circ} \mathrm{C}\right)$. The field pilot study lasted for three months in the Xinjiang Oilfield in 2014.

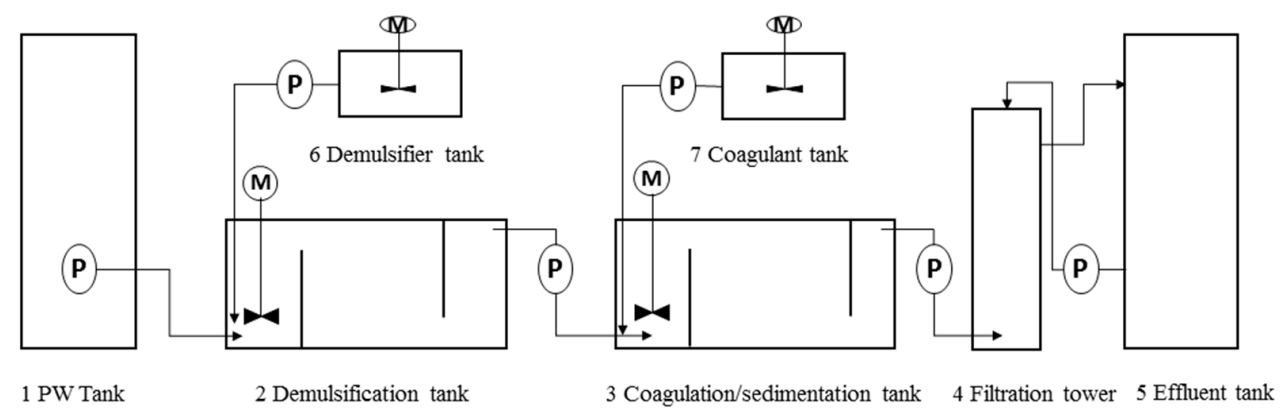

Figure 2. Flow diagram of the pilot experimental setup. 


\subsection{Measurements}

The residual polymer concentration in PW was measured using the starch-cadmium iodide method [15]. The dispersed oil in PW was extracted by petroleum ether and the adsorbance of the extract was examined on an ultraviolet spectrophotometer (PERSEE, Beijing, China) at $430 \mathrm{~nm}$ [16]. The residual petroleum sulfonate content was measured using the methylene blue spectrophotometry method. The anionic petroleum sulfonate in PW reacts with the cationic methylene blue (MB) to produce a blue compound, which can be extracted by trichloromethane. The adsorbance of the extract was then measured at $652 \mathrm{~nm}$ [17].

The emulsion stability of the samples before and after demulsification were tested by multiple light scattering (Turbiscan Lab Expert, Formulaction, Toulouse, France) [18-20]. The turbiscan stability index (TSI) was used to assess stability of the emulsion, which is shown in the equation below.

$$
T S I=\sum_{i} \frac{\sum_{h}\left|\operatorname{Scan}_{i}(h)-\operatorname{Scan}_{i-1}(h)\right|}{\mathrm{H}}
$$

where $\mathrm{H}$ represents sample height from the bottom of the cell to the meniscus and $\operatorname{Scan}_{i-1}(h)$ represents the intensity of scanning light (time is $i-1$, measurement cell height is $h$ ).

Pendant drop tensionmeter (Tracker, IT Concept, Lyon, France) was used to determine the dilational rheology properties of oil-water interface [21,22]. The inner phase was n-decane and the out phase was a simulated solution. After formation of an oil drop, the dilational modulus began to scan with a frequency of $0.1 \mathrm{~Hz}$ until the dynamic interface tension reaches the equilibrium and then swept dilational rheology with a varying frequency from 0.005 to $0.1 \mathrm{~Hz}$ [23,24]. The experiment was performed at $30.0 \pm 0.1^{\circ} \mathrm{C}$.

The zeta potentials of the samples were measured on Zetasizer Nano ZS (Malvern instruments Ltd., Malvern, UK) with three replicates and the average value was used.

\section{Results and Discussion}

\subsection{The Demulsification Performance of Different Demulsifiers}

In order to choose the most efficient demulsifier for the pilot scale tests, nine demulsifiers (five cationic and four nonionic) were employed in treating PW from polymer/surfactant flooding in the Xinjiang Oilfield and its performance was shown in Figure 3. In comparison with the nonionic demulsifers, the cationic ones in general exhibited much better oil removal efficiency with CP-1 as the best one. In this study, the petroleum sulfonate concentration in PW was $35 \mathrm{mg} / \mathrm{L}$, as shown in Table 1. A previous study on simulated produced liquid from EOR has shown that the optimum molecule weight of the cationic demulsifiers for demulsification was closely related with the surfactant concentration [11]. Thus, the relatively low performance of CP-4 might be associated with petroleum sulfonate concentration in PW.

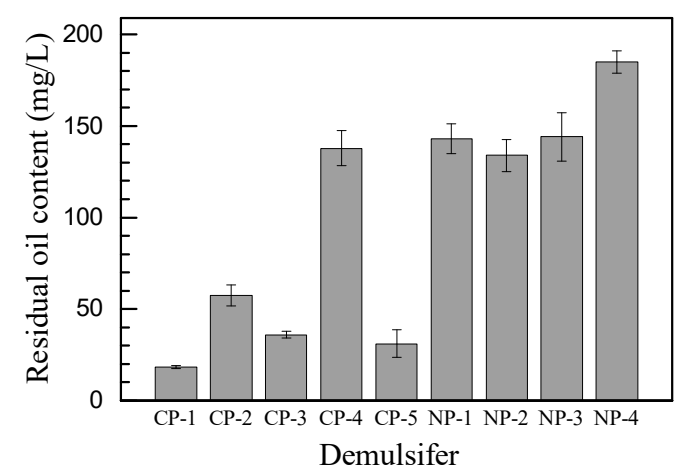

Figure 3. Performance of demulsifiers in treating EOR PW from the Xinjiang Oilfield. Oil content in $\mathrm{PW}, 358.5 \mathrm{mg} / \mathrm{L}$. Dose of demulsifiers, $500 \mathrm{mg} / \mathrm{L}$. Temperature, $40^{\circ} \mathrm{C}$. 
Table 1. Characteristics of produced water from HPAM/petroleum sulfonate flooding in the Xinjiang Oilfield.

\begin{tabular}{cccc}
\hline Parameter & Value & Parameter & Value \\
\hline $\mathrm{pH}$ & 7.5 & Salinity & $8305.6 \mathrm{mg} / \mathrm{L}$ \\
Oil content & $128.3 \sim 7364.4 \mathrm{mg} / \mathrm{L}$ & $\mathrm{Mg}^{2+}$ & $36.9 \mathrm{mg} / \mathrm{L}$ \\
HPAM & $177.1 \mathrm{mg} / \mathrm{L}$ & $\mathrm{Ca}^{2+}$ & $67.9 \mathrm{mg} / \mathrm{L}$ \\
Petroleum sulfonate & $35.1 \mathrm{mg} / \mathrm{L}$ & $\mathrm{K}^{+}+\mathrm{Na}^{+}$ & $2602.7 \mathrm{mg} / \mathrm{L}$ \\
Suspended solids & $153.7 \sim 990.0 \mathrm{mg} / \mathrm{L}$ & $\mathrm{Cl}^{-}$ & $1276.5 \mathrm{mg} / \mathrm{L}$ \\
Zeta potential & $-32.5 \mathrm{mV}$ & $\mathrm{SO}_{4}{ }^{2-}$ & $2847.0 \mathrm{mg} / \mathrm{L}$ \\
\hline
\end{tabular}

The effect of CP-1 dose on demulsification was further investigated, which is shown in Figure 4. The oil content was reduced from $358.5 \mathrm{mg} / \mathrm{L}$ to less than $20 \mathrm{mg} / \mathrm{L}$ and the HPAM content from $177.1 \mathrm{mg} / \mathrm{L}$ to $50 \mathrm{mg} / \mathrm{L}$ with the increase of the CP-1 dose from 0 to $500 \mathrm{mg} / \mathrm{L}$. The petroleum sulfonate content, however, only decreased from 35.0 to $18.8 \mathrm{mg} / \mathrm{L}$ over the whole CP-1 dose range. At the same time, the zeta potential increased from $-32.5 \mathrm{mV}$ to $-19.7 \mathrm{mV}$. It is, thus, assumed that charge neutralization between the anionic HPAM/surfactant and cationic demulsifier has reduced the net charge on the surface of dispersed oil droplets, which facilitated the coalescence of oil droplets [25].

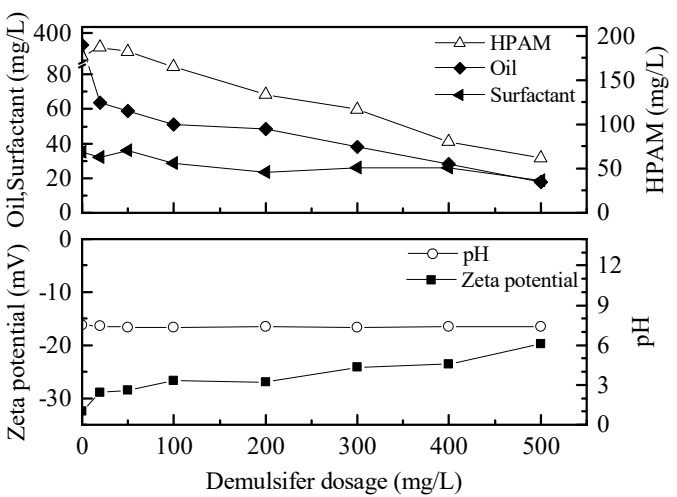

Figure 4. Effect of CP-1 dose on demulsification of EOR PW from the Xinjiang Oilfield. Oil content in $\mathrm{PW}, 358.5 \mathrm{mg} / \mathrm{L}$. Temperature, $40^{\circ} \mathrm{C}$.

The whole demulsification process at a CP-1 dose of $300 \mathrm{mg} / \mathrm{L}$ was monitored by the multiple light scattering method, which is shown in Figure 5. The delta transmission light intensity of the treated PW showed many ups and downs, which suggests a coalescence of the dispersed crude oil droplets may have occurred. The transmission light intensity increased from the initial $0.2 \%$ to $60 \%$ within $10 \mathrm{~min}$. At the same time, the turbiscan stability index (TSI) also sharply increased from 0.4 to 40.0 within $30 \mathrm{~min}$, which indicates that the demulsification processes of the PW by CP-1 proceeded very quickly.
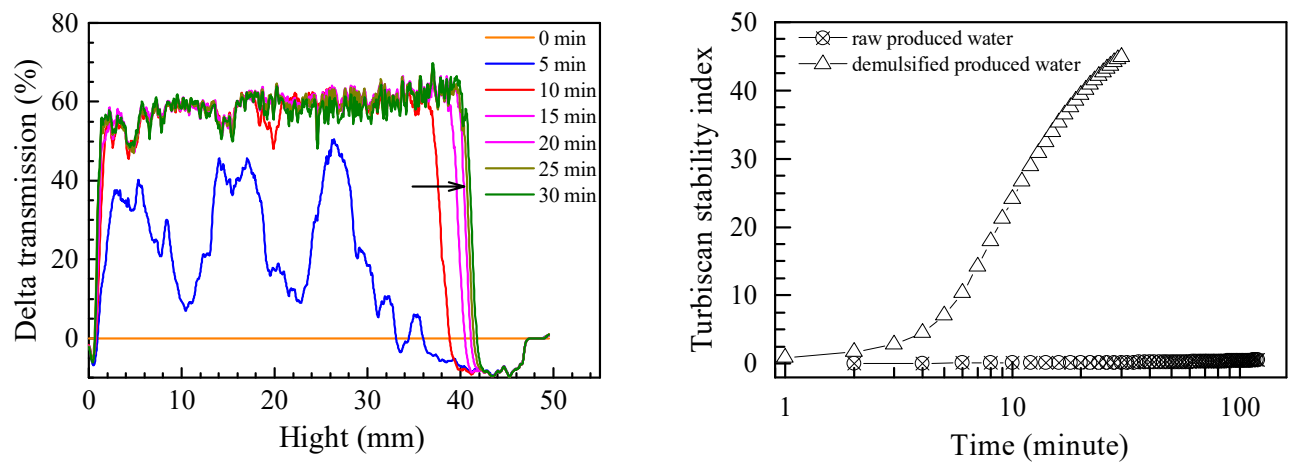

Figure 5. Variations of delta transmission light intensity and TSI with time. Oil content in PW, $358.5 \mathrm{mg} / \mathrm{L}$. Dose of demulsifiers, $300 \mathrm{mg} / \mathrm{L}$. Temperature, $40^{\circ} \mathrm{C}$. 


\subsection{The Performance of the Pilot Treatment Plant}

As shown in Figure 6, the oil content could be removed from 128 7364 mg/L in the influent to 30 300 mg/L through demulsification with $350 \mathrm{mg} / \mathrm{L} \mathrm{CP}-1$ and further to below $10 \mathrm{mg} / \mathrm{L}$ through coagulation with $500 \mathrm{mg} / \mathrm{L}$ PAC. Thus, the effectiveness of the cationic demulsifier in breaking down the emulsion formed in EOR PW was verified through the field pilot study. At the same time, the suspended solids were reduced from 153 990 mg/L to 310 610 and 20 82 mg/L along with HPAM from 176.9 177.1 $\mathrm{mg} / \mathrm{L}$ to $93.0 \sim 95.3$ and $2.8 \sim 3.9 \mathrm{mg} / \mathrm{L}$ through demulsification and coagulation/sedimentation, respectively. It seems that part of HPAM was transferred into the oil phase and part was adsorbed by the flocs after flocculation. However, petroleum sulfonate was not removed very much in this system (from $35.5 \sim 43.8 \mathrm{mg} / \mathrm{L}$ in the influent to $25.5 \sim 26.5 \mathrm{mg} / \mathrm{L}$ in the final effluent). The field study on the treatment of PW from polymer/surfactant flooding is still very few. A pilot study for the treatment of PW from polymer flooding has shown that, without the use of demulsifiers, a complicated process including double coagulation and flotation, which is followed by anthracite filtration and activated carbon adsorption, would be required to remove oil to less than $10 \mathrm{mg} / \mathrm{L}$ [4]. Thus, the application of the cationic demulsifier would make the PW treatment process much simpler and more efficient.

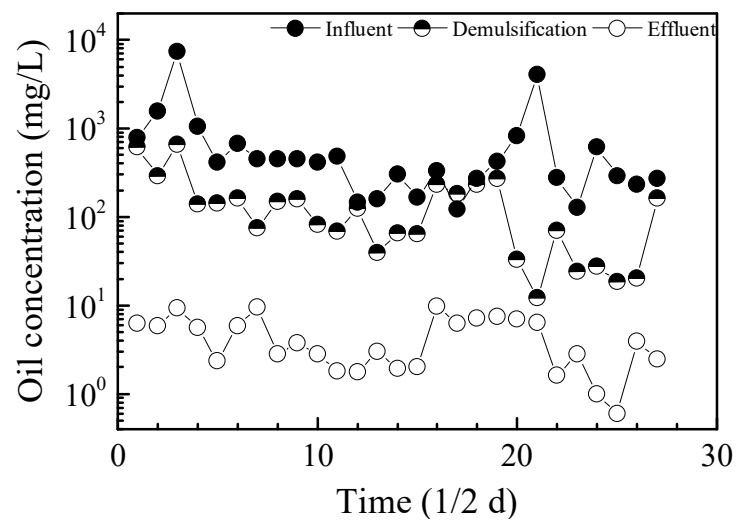

Figure 6. Oil removal performance of the pilot plant in the Xinjiang Oilfield. CP-1 dose, $350 \mathrm{mg} / \mathrm{L}$. PAC dose, $500 \mathrm{mg} / \mathrm{L}$. Temperature, $14 \sim 22{ }^{\circ} \mathrm{C}$.

\subsection{Interfacial Tension and Dilational Rheology Analysis of the Simulated Demulsification Processes}

To explore the possible demulsification mechanism by demulsifiers, a simulated EOR PW treatment process was followed using the interfacial tension and dilational rheology analysis approaches, which are shown in Figure 7. It was found that the interfacial tension of the oil-water interface increased from 7 to $15 \sim 20 \mathrm{mN} / \mathrm{m}$ when CP-1 was added with a dose of 10 to $100 \mathrm{mg} / \mathrm{L}$ while little change was observed $(7$ to $10 \mathrm{mN} / \mathrm{m})$ with the addition of NP-4. A marked increase of the dilational elasticity was also observed when the CP-1 concentration grew from 0 to $50 \mathrm{mg} / \mathrm{L}$. At the same time, only a slight increase was observed for the nonionic demulsifier, which grew from 0 to $100 \mathrm{mg} / \mathrm{L}$ (Figure 7B). Regarding dilational viscosity, only minor changes were observed for both demulsifiers. Thus, the differences in demulsification performance of the two demulsifiers might be associated with their different impacts to the oil-water interfacial tension and dilational elasticity.

It has been reported that the adsorption of HPAM on the oil-water interface increases the steric barriers of dispersed oil droplets, which leads to the enhanced stability of oil/water emulsion [16,26-28]. Polymers (such as polystyrene sulfonate sodium, PSS) have the ability to form complexes with the oppositely charged molecules (such as hexadecanetrimethyl-ammonium bromide, CTAB) by electrostatic attraction or hydrophobic interaction [29,30]. In this study, the negatively charged HPAM might have formed complexes with the added demulsifier CP-1, which would deplete HPAM from the dispersed oil droplets surface [29,31]. Thus, the steric barriers between the dispersed oil droplets formed by HPAM were removed, which results in the weakening of the 
oil-water film on the dispersed oil droplets surface. On the other hand, it would be very difficult for the nonionic demulsifiers to form complexes with HPAM, which could explain the poor demulsification performance. The increased dilational elasticity transferred the adsorbed layer into a rigid and fragile one due to the film rupture, which also improved the coalescence ratio of the collision of dispersed oil droplets [32,33].
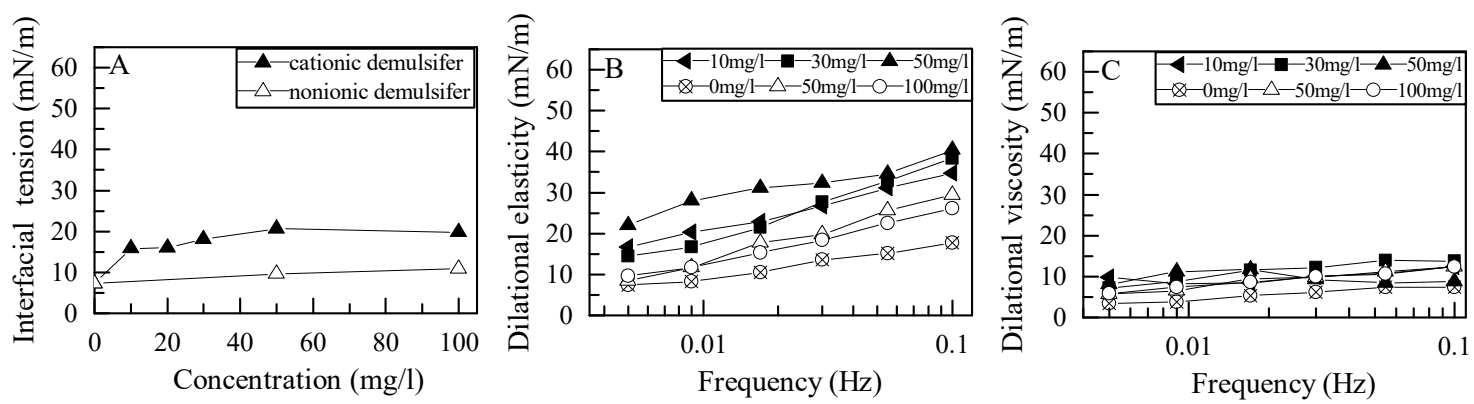

Figure 7. Interfacial tension and dilational rheology properties as a function of demulsifier concentration. (A) Interfacial tension, (B) dilatational elasticity, and (C) dilatational viscosity. The water phase contained $30 \mathrm{mg} / \mathrm{L}$ petroleum sulfonate and $100 \mathrm{mg} / \mathrm{L}$ HPAM and the oil phase was n-decane. The filled symbols represent the system with a cationic demulsifier CP-1 and the blank symbols represent the nonionic demulsifier NP-4.

\section{Conclusions}

In comparison with the nonionic demulsifiers, the cationic ones exhibited much better performance in the destabilization of PW from polymer/surfactant flooding in the Xinjiang Oilfield. The excellent performance of the cationic demulsifier was further verified in the field pilot study in the Xinjiang Oilfield. The oil in the influent PW was reduced from $128 \sim 7364 \mathrm{mg} / \mathrm{L}$ to $30 \sim 300 \mathrm{mg} / \mathrm{L}$ by adding a dosage of $350 \mathrm{mg} / \mathrm{L}$ cationic demulsifier CP-1. It was further reduced to less than $10 \mathrm{mg} / \mathrm{L}$ with the addition of $500 \mathrm{mg} / \mathrm{L}$ PAC. At the same time, HPAM in PW was almost completely removed. With its strong charge neutralization capacity, the cationic demulsifier could drag HPAM from the oil-water interface and destabilize the emulsion.

Author Contributions: Data analysis was carried out by F.L., Y.G. designed the work, M.Y. contributed to the revising of the manuscript, D.C. carried out the experiments and writing.

Funding: This research was supported by the Hi-tech Research and Development Project of the Ministry of Science and Technology, People's Republic of China, and grant number was 2012AA063401. The APC was also founded by the same project.

Conflicts of Interest: The authors declare no conflicts of interest.

\section{References}

1. Alvarado, V.; Manrique, E. Enhanced oil recovery: An update review. Energies 2010, 3, 1529-1575. [CrossRef]

2. Manrique, E.; Thomas, C.; Ravikiran, R.; Izadi, M.; Lantz, M.; Romero, J.; Alvarado, V. EOR: Current status and opportunities. In Proceedings of the SPE Improved Oil Recovery Symposium, Tulsa, OK, USA, 24-28 April 2010.

3. Fakhru'l-Razi, A.; Pendashteh, A.; Abdullah, L.C.; Biak, D.R.A.; Madaeni, S.S.; Abidin, Z.Z. Review of technologies for oil and gas produced water treatment. J. Hazard. Mater. 2009, 170, 530-551. [CrossRef] [PubMed]

4. Al-Maamari, R.S.; Sueyoshi, M.; Tasaki, M.; Kojima, K.; Okamura, K. Polymer-Flood Produced-WaterTreatment Trials. Oil Gas Facil. 2014, 3, 89-100. [CrossRef]

5. Zhang, Y.; Gao, B.; Lu, L.; Yue, Q.; Wang, Q.; Jia, Y. Treatment of produced water from polymer flooding in oil production by the combined method of hydrolysis acidification-dynamic membrane bioreactor-coagulation process. J. Pet. Sci. Eng. 2010, 74, 14-19. [CrossRef] 
6. Deng, S.; Bai, R.; Chen, J.P.; Yu, G.; Jiang, Z.; Zhou, F. Effects of alkaline/surfactant/polymer on stability of oil droplets in produced water from ASP flooding. Colloids Surf. A Physicochem. Eng. Asp. 2002, 211, 275-284. [CrossRef]

7. Mohebali, G.; Kaytash, A.; Etemadi, N. Efficient breaking of water/oil emulsions by a newly isolated de-emulsifying bacterium, Ochrobactrum anthropi strain RIPI5-1. Colloids Surf. B Biointerfaces 2012, 98, 120-128. [CrossRef] [PubMed]

8. Mutyala, S.; Fairbridge, C.; Paré, J.R.J.; Bélanger, J.M.R.; Ng, S.; Hawkins, R. Microwave applications to oil sands and petroleum: A review. Fuel Process. Technol. 2010, 91, 127-135. [CrossRef]

9. Long, X.W.; Zhang, G.L.; Shen, C.; Sun, G.S.; Wang, R.X.; Yin, L.J.; Meng, Q. Application of rhamnolipid as a novel biodemulsifier for destabilizing waste crude oil. Bioresour. Technol. 2013, 131, 1-5. [CrossRef] [PubMed]

10. Perles, C.E.; Volpe, P.L.O.; Bombard, A.J.F. Study of the Cation and Salinity Effect on Electrocoalescence of Water/Crude Oil Emulsions. Energy Fuels 2012, 26, 6914-6924. [CrossRef]

11. Nguyen, D.; Sadeghi, N.; Houston, C. Chemical Interactions and Demulsifier Characteristics for Enhanced Oil Recovery Applications. Energy Fuels 2012, 26, 2742-2750. [CrossRef]

12. Yau, Y.H.; Rudolph, V.; Ho, K.C.; Lo, C.C.M.; Wu, K.C. Evaluation of different demulsifiers for Marpol oil waste recovery. J. Water Process Eng. 2017, 17, 40-49. [CrossRef]

13. Hirasaki, G.J.; Miller, C.A.; Raney, O.G.; Poindexter, M.K.; Nguyen, D.T.; Hera, J. Separation of Produced Emulsions from Surfactant Enhanced Oil Recovery Processes. Energy Fuels 2011, 25, 555-561. [CrossRef]

14. Duan, M.; Ma, Y.; Fang, S.; Shi, P.; Zhang, J.; Jing, B. Treatment of wastewater produced from polymer flooding using polyoxyalkylated polyethyleneimine. Sep. Purif. Technol. 2014, 133, 160-167. [CrossRef]

15. Scoggins, M.W.; Miller, J.W. Determination of Water-Soluble Polymers Containing Primary Amide Groups Using the Starch-Triiodide Method. Soc. Pet. Eng. J. 1979, 19, 151-154. [CrossRef]

16. Ma, B.; Gao, B.; Yue, Q. Study on emulsification stability of wastewater produced by polymer flooding. J. Pet. Sci. Eng. 2013, 110, 27-31. [CrossRef]

17. Chen, Z.-G.; Peng, Y.-R.; Xie, F.; Jiang, W.-Y.; Zou, H.; Qiu, H.-D.; Chen, J.-H. Determination of anionic surfactant in surface water by resonance light-scattering technology. Int. J. Environ. Anal. Chem. 2010, 90, 573-585. [CrossRef]

18. Celia, C.; Trapasso, E.; Cosco, D.; Paolino, D.; Fresta, M. Turbiscan Lab (R) Expert analysis of the stability of ethosomes (R) and ultradeformable liposomes containing a bilayer fluidizing agent. Colloids Surf. B Biointerfaces 2009, 72, 155-160. [CrossRef] [PubMed]

19. Mengual, O.; Meunier, G.; Cayré, I.; Puech, K.; Snabre, P. TURBISCAN MA 2000: Multiple light scattering measurement for concentrated emulsion and suspension instability analysis. Talanta 1999, 50, 445-456. [CrossRef]

20. Wulff-Pérez, M.; Torcello-Gómez, A.; Gálvez-Ruíz, M.J.; Martín-Rodríguez, A. Stability of emulsions for parenteral feeding: Preparation and characterization of $\mathrm{o} / \mathrm{w}$ nanoemulsions with natural oils and Pluronic f68 as surfactant. Food Hydrocoll. 2009, 23, 1096-1102. [CrossRef]

21. Song, X.-W.; Zhang, L.; Cao, X.-L.; Li, Z.-Q.; Zhang, L.; Luo, L.; Zhao, S. Surface dilational rheological and lamella properties of branched alkyl benzene sulfonate solutions. Colloids Surf. A Physicochem. Eng. Asp. 2012, 412, 64-71. [CrossRef]

22. Li, X.-L.; Zhang, L.; Gong, Q.-T.; Zhang, L.; Zhao, S.; Yu, J.-Y. Interfacial Dilational Properties of Tri-Substituted Alkyl Benzene Sulfonates. Acta Phys.-Chim. Sin. 2010, 26, 631-637.

23. Huang, Y.-P.; Zhang, L.; Zhang, L.; Luo, L.; Zhao, S.; Yu, J.-Y. Dynamic interfacial dilational properties of hydroxy-substituted alkyl benzenesulfonates. J. Phys. Chem. B 2007, 111, 5640-5647. [CrossRef] [PubMed]

24. Zhang, L.; Wang, X.-C.; Gong, Q.-T.; Zhang, L.; Luo, L.; Zhao, S.; Yu, J.-Y. Interfacial dilational properties of tri-substituted alkyl benzene sulfonates at air/water and decane/water interfaces. J. Colloid Interface Sci. 2008, 327, 451-458. [CrossRef] [PubMed]

25. Deng, S.; Yu, G.; Jiang, Z.; Zhang, R.; Ting, Y.P. Destabilization of oil droplets in produced water from ASP flooding. Colloids Surf. A Physicochem. Eng. Asp. 2005, 252, 113-119. [CrossRef]

26. Robertson, E.J.; Carpenter, A.P.; Olson, C.M.; Ciszewski, R.K.; Richmond, G.L. Metal Ion Induced Adsorption and Ordering of Charged Macromolecules at the Aqueous/Hydrophobic Liquid Interface. J. Phys. Chem. C 2014, 118, 15260-15273. [CrossRef] 
27. Robertson, E.J.; Richmond, G.L. Molecular Insights in the Structure and Layered Assembly of Polyelectrolytes at the Oil/Water Interface. J. Phys. Chem. C 2014, 118, 28331-28343. [CrossRef]

28. Beaman, D.K.; Robertson, E.J.; Richmond, G.L. Ordered polyelectrolyte assembly at the oil-water interface. Proc. Natl. Acad. Sci. USA 2012, 109, 3226-3231. [CrossRef] [PubMed]

29. Fang, H.-B. Dilational viscoelasticity of anionic polyelectrolyte/surfactant adsorption films at the water-octane interface. Colloid Polym. Sci. 2009, 287, 1131-1137. [CrossRef]

30. Guzman, E.; Llamas, S.; Maestro, A.; Fernandez-Pena, L.; Akanno, A.; Miller, R.; Ortega, F.; Rubio, R.G. Polymer-surfactant systems in bulk and at fluid interfaces. Adv. Colloid Interface Sci. 2016, 233, 38-64. [CrossRef] [PubMed]

31. Kristen, N.; Vullings, A.; Laschewsky, A.; Miller, R.; von Klitzing, R. Foam Films from Oppositely Charged Polyelectolyte/Surfactant Mixtures: Effect of Polyelectrolyte and Surfactant Hydrophobicity on Film Stability. Langmuir 2010, 26, 9321-9327. [CrossRef] [PubMed]

32. Noskov, B.A. Dilational surface rheology of polymer and polymer/surfactant solutions. Curr. Opin. Colloid Interface Sci. 2010, 15, 229-236. [CrossRef]

33. Fauser, H.; Von, K.R.; Campbell, R.A. Surface Adsorption of Oppositely Charged C14TAB-PAMPS Mixtures at the Air/Water Interface and the Impact on Foam Film Stability. J. Phys. Chem. B 2015, 119, 348-358. [CrossRef] [PubMed]

(C) 2018 by the authors. Licensee MDPI, Basel, Switzerland. This article is an open access article distributed under the terms and conditions of the Creative Commons Attribution (CC BY) license (http://creativecommons.org/licenses/by/4.0/). 